\title{
Chronic Viral Hepatitis
}

National Cancer Institute

\section{Source}

National Cancer Institute. Chronic Viral Hepatitis. NCI Thesaurus. Code C82979.

Chronic hepatitis caused by viruses, most commonly hepatitis viruses B and C. 